\title{
COMMENT
}

DOI: $10.1057 /$ s41599-018-0087-7

\section{Future cities: asserting public governance}

Simon Joss (1) ${ }^{1}$

\begin{abstract}
The smart city has become a main prism through which urban futures are viewed. With it comes the promise of big data technology enabling more resource-efficient urban systems and improved governance. Increasingly, however, this technocentric view is being challenged, at least rhetorically, by seeking to place people at the heart of smart city development. Yet, especially in the case of the UK, such development typically takes place within a governance context which marginalises established planning and decision processes, thus arguably weakening public accountability. Moreover, the norms of engagement change in that citizens are assigned more of an entrepreneurial role as co-producers of data-driven information. It becomes necessary, therefore, to reconsider, as well as reinvigorate the place of the public in the future city. This article seeks to do so by making the case, on one hand, for strengthening institutional frameworks and, on the other, advancing a more active role for citizens to become involved in actualising and scrutinising future cities.
\end{abstract}

\footnotetext{
${ }^{1}$ Department of Politics and International Relations, University of Westminster, Westminster, England. Correspondence and requests for materials should be addressed to S.J. (email: josss@westminster.ac.uk)
} 


\section{'City of tomorrow' arrives in London}

The future city has arrived. At least, this may be the impression Londoners gain when encountering any of the growing numbers of 'smart benches' recently installed across the capital. Prominently branded Ford-City of Tomorrow, the solar-powered benches offer free Wi-Fi and charging facilities. Described as "an oasis of tech on the high street" in one press report (Moldrich, 2017), the benches double up as environmental monitoring station for noise, carbon dioxide, humidity and temperature; information which is "free of charge to bench users and participating London boroughs and could help inform future decisions", according to the official press release (Ford Social, 2017). While Ford appears to act as main sponsor, the 'smart benches' are the result of a collaboration with a company specialising in developing "green and smart urban devices to provide people with energy, connectivity and local information in public spaces" (Strawberry Energy, nd), and so far three London boroughs (Islington, Lewisham, Southwark).

fter Hollands (2008, p 304), early on, provocatively asked "will the real smart city please stand up?", followed by Shelton et al. (2015, p 305) urging analysis into "the 'actually existing smart city"' (as opposed to far-fetched imaginaries and totemic 'clean-slate' projects), are the City of Tomorrow benches, then, a sign that the smart city has finally arrived (at least in London)? If so, what is the evidence that the original top-down smart city approach-much criticised for its technocentricity-has given way to a more bottom-up approach? The latter, as part of growing calls to "rethink smart cities from the ground up" (Saunders and Baeck, 2015), posits that "collaborative technologies" offer the opportunity to "engage and enable citizens" and, thus, to "help citizens themselves to shape the future of their cities" (NESTA, 2015). Echoes of more peopleoriented smart cities can be increasingly heard in policy and public discourse, so much so that even the British Standards Institution, the national body in the business of issuing technical standards, concluded that "the key challenge around smart cities is not technological but about people" (BSI, 2015, p 10) and, consequently, arguing for citizen-centric innovation ("for citizens, the benefits of (smart city) include....an increased sense of democratic participation"; ibid, p 7). While this rhetorical turn should be welcomed by anyone interested in maintaining and nurturing a vibrant urban politics, at the same time it should trigger probing questions to avoid simplistic and cursory assertions about the potential for public participation in the future city. Indeed, the role of the public in the smart city is an inherently complex and arguably also a problematic one, which can be seen interacting at three levels: institutional arrangements, conceptual discourses, and on-the-ground practices.

\section{The challenge of public governance: institutions, discourses, practices}

With the discussion about more people-oriented smart city innovation typically focusing on how people can be practically enroled into particular activities and events ('hackathons', 'living labs' etc.), the wider institutional arrangements risk being overlooked. These, however, are instrumental in shaping the governance context in which smart city initiatives are played out. Against the background of the smart city originally driven by corporate interests and a technological agenda-IBM is sometimes claimed as originator (dating back to 2008)-it is not entirely surprising that governmental uptake has typically been led by business and innovation agencies, with (urban) planning departments marginalised. The UK's Future Cities Demonstrator ${ }^{1}$ initiative is a case in point (Taylor Buck and While, 2015; Caprotti et al. 2016). Launched in 2012 as a national competition intended to act as a catalyst for smart city innovation, the initiative was funded by the Department for Business, Innovation and Skills (BIS; now, the Department for Business, Energy and Industrial Strategy) and implemented through the Technology Strategy Board (TSB; now, Innovate UK). Arup, an international consultancy firm, was enlisted early on to write the concept report and define implementation guidelines, and subsequently involved in writing the bids on behalf of several cities participating in the competition. Quite absent from this process was the Department for Communities and Local Government (DCLG), which traditionally and formally has been in charge of urban planning. In parallel, and again initiated by BIS, the British Standards Institution was commissioned to publish a series of smart city standards, effectively to act as new planning tools for smart city implementation (BSI, nd).

Overall, as a result, the smart city's conceptual and practical development in the UK has largely taken place outside formal planning processes, thus arguably bypassing established avenues for public consultation, participation and accountability. While this should be of concern given claims made in favour of a more citizen-centric approach, it is in line with a prevalent discourse which posits smart cities as catalyst for 'transformative governance' beyond traditional structures, or as the Melbourne Smart City vision document (incidentally, again authored by Arup on behalf of the city) states: "governance models remain in the 20th century...the smart city is so different in essence to the 20th century city that the governance models and organisational frameworks themselves must evolve" (Arup, 2010, p 4).

The observed shifts in institutional arrangements, then, are accompanied and reinforced by significant discursive shifts, which not only move the conceptual emphasis from technology to governance as key driver of the smart city, but moreover to a mode of governance which espouses a different kind of publicness and citizen engagement. The BSI smart city standards-which as official, codified texts are an authoritative source of information-underline the importance of public engagement while at the same time recasting it in significantly new ways (Joss et al. 2017). On one hand, citizens are promoted as service users who interact through digital data exchange with service providers; they are thereby drawn into the process of producing data for use by utilities and other urban service operators, while consuming the data conveyed through smart devices. On the other, citizens are encouraged to get involved entrepreneurially, as co-creators, to help develop solutions for urban challenges. Notably, citizens as entrepreneurs are expected to provide more for themselves: "citizens can use open data to develop and use new applications to manage their lives more effectively and to collaborate to tackle joint challenges together... The opening up of more useful data to the public can...enable citizens to provide effective peer support to each other" (BSI, 2015, pp 7-8). Public engagement, then, is conceptualised in relation to, and subsumed within the smart city as "virtual business infrastructure based around customer needs", as part of which citizens are co-opted along other socioeconomic actors into the "city information marketplace" (BSI, 2014, p 15; p 32). This obviously raises a number of important issues about the nature and effects of this new agency-often glossed over, yet in need of closer consideration-such as the potential for new inequalities ('digitally disenfranchised'), the changing role of citizens as 'citizen-consumers' or 'prosumers', and the provenance and accountability of data as new medium of deliberation. Furthermore, it draws attention to the relative absence of a collective, normative articulation of the public sphere: underlying questions about public choice, social justice and sustainable 
development, among others, seem marginalised and thus not opened up to critical deliberation and public scrutiny.

These institutional and discursive contexts inevitably influence how on-the-ground practices are constituted and performed. In the case of the City of Tomorrow benches, the local councils involved are named, although there is no mistaking that Ford claims this public space. (Tellingly, a contact phone number is listed for the private partners, but not for the councils; and whereas information aplenty on the former's websites, nothing is found on the latter's.) Concerning the mode of publicness envisaged, while the benches are certainly not claimed to be some groundbreaking bottom-up deliberative forum, the accompanying discourse nevertheless reveals an aspirational publicness: to connect people (and their local councils), to provide them with useful information and, thus, to help inform future decisions. As such, it taps into the narrative of the smart city designed for citizens as collaborative prosumers.

Beyond this particular example, a recent comparative study of 68 initiatives across six UK cities (all of which participated in the Future Cities Demonstrator competition) highlighted three interrelated trends concerning how the public is enroled into the smart city (Cowley et al., 2017). First, whereas in approx. two thirds of activities engagement was either predominantly in an entrepreneurial or service user mode, less than five percent of activities involved engagement with political decision-making and deliberation through institutional channels. While this finding may be expected from the aforementioned wider institutional and discursive trends, the significantly lower level of political engagement modality is nevertheless surprising, given that these activities were initiated by, and related to, local actors and institutions 'from the ground up'. Second, not only did a majority of activities seek to mobilise the public in a service user or entrepreneurial role, but these also turned out to be more permanent; on their part, activities involving the public in civic or political deliberation were much more likely to be ephemeral. Finally, overall, the level of public engagement across activities was found to be relatively low (with participation often in the dozens or low hundreds), which further suggests that the future city-at least as currently enacted-takes shape in the margins of urban planning and politics.

\section{Reinvigorating the public city}

It is becoming evident, therefore, that the place of the public in the smart city requires further exploration and critical probing, to be addressed productively at three interacting levels: institutional, discursive, and practical. In doing so, however, one needs to be careful neither to take an overly nostalgic view of past (and present) urbanism, nor to rely on simplistic notions of the public and related governance practices. Concerning the former, while it is true that antecedents of the smart city-the sustainable city and eco city, among others-contained a more explicit articulation of, and commitment to, social issues (e.g., De Jong et al., 2015), in practice the predominant technocratic approach to sustainable urban development, with its fixation on indicators, benchmarks and standards, has effectively limited opportunities for public deliberation (e.g., Joss et al., 2015). Where public participation has been attempted, this has often turned into tokenistic exercises. That said, there has at least been a more direct link to formal decision-making processes involving public engagement and accountability, such as through Local Agenda 21 and more recently the Sustainable Development Goals (e.g., Caprotti et al., 2017). Concerning the notion of the public, it is by now well established in political theory and policy analysis that the public of old-as a singular whole, expressing the common good-is on the decline, increasingly replaced with what has been termed a 'heterogeneous public' characterised by a multitude of co-existing 'publics' (e.g., Young, 1989; Fraser, 1990; Newman and Clarke, 2009). While this does present a more complex picture, it positively prompts nuanced theorising and probing analysis of how, and to what effect, diverse publics are variously enroled into urban policy and politics.

If, therefore, the task is to reconsider and assert the role of the public within the context of a discourse on the future city, the following may be useful starting points: first, there is ample scope for improving the transparency of, and accessibility to, institutional decisions about where and how to implement smart/future city programmes. Rather than through separate (sometimes obscure) channels, implementation should be aligned with established planning structures and processes, which have an important role in nurturing and safeguarding public accountability. This resonates particularly strongly (though not exclusively) in the UK context, where the uptake of future-smart city programmes has coincided with a significant weakening of the planning system. It is, then, also through such institutionalised public deliberation that a wider normative debate about the purpose and merit of future city innovation can be conducted. Consequently, what is required are new institutional designs which create the necessary experimental space for smart city innovation, while at the same time ensuring that resulting ideas and practices are aligned with institutional decision-making and subject to public scrutiny. Second, if one accepts within the discourse on smart city that citizens could potentially gain new opportunities and responsibilities as co-producers of data and cocreators of new collaborative governance, then this will require proper conceptual elaboration and practical investment. Otherwise, talk of 'people-centric' future cities risks being glossy and related practices perfunctory, thereby rightly provoking cynical responses. Hence, for example, special efforts are required to equip citizens with information and skills to enable them-beyond mere data feeding-to access, analyse and utilise (big) data. Given often stark information asymmetries between data holders and users, not least also in relation to matters of social inequality, active intervention and sustained support are needed. This then also prompts wider questions about how data may be owned, shared and assured within the public sphere. Once again, this highlights the need for careful design of processes to allow individuals and communities to engage meaningfully-that is, with active voice and embedded in decision processes-in the smart city. Importantly, such engagement should not remain limited to questions of urban service delivery-a dominant framing in smart city discourse-but essentially extend to wider normative questions concerning collective aspirations and priorities for the contemporary, as well as future city.

To occupy a meaningful public place in the City of Tomorrow, the smart benches dotted across London need to be more than opportunistically conceived, atomistic street furniture. They, and the many new innovations promised under the banner of future city, need to justify and demonstrate claims made that people will inhabit a central place in the future smart city.

Received: 26 October 2017 Accepted: 7 March 2018

Published online: 03 April 2018

\section{Notes}

1 The two terms 'smart city' and 'future city', especially in the UK policy context, are complementary and sometimes used interchangeably. According to the British Standards Institution, "the future of cities is the focus of the challenge facing humankind's aspiration to attain or maintain a high quality, but sustainable, way of living. Smart cities can be seen as a response to this challenge” (BSI, 2014, p 3). 


\section{References}

Arup (2010) Melbourne smart city. http://www.cityofsound.com/files/ c40_melbourne_report_final_email.pdf Accessed 20 Oct 2017

BSI (nd) Smart cities. https://www.bsigroup.com/en-GB/smart-cities/ Accessed 20 Oct 2017

BSI (2015) Smart cities overview-guide. BSI Standards Publication PD8100. British Standards Institution, London

BSI (2014) Smart city framework-guide to establishing strategies for smart cities and communities. BSI Standards Publication PAS 181. British Standards Institution, London

Caprotti F, Cowley R, Flynn A, Joss S, Yu L (2016) Smart-eco cities in the UK: trends and city profiles 2016. University of Exeter, Exeter

Caprotti F, Cowley R, Datta A, Castan Broto V, Gao E, Georgson L, Herrick C, Odendaal N, Joss S (2017) The new urban agenda: key opportunities and challenges for policy and practice. J Urban Res Practice https://doi.org/ $10.1080 / 17535069.2016 .1275618$.

Cowley R, Joss S, Dayot Y (2017) The smart city and its publics: insights from across six UK cities. J Urban Res Practice https://doi.org/10.1080/ 17535069.2017.1293150.

De Jong M, Joss S, Schraven D, Zhan C, Weijnen M (2015) Sustainable-smart-resilient-low carbon-eco-knowledge cities; making sense of a multitude of concepts promoting sustainable urbanization. J Clean Prod 109:25-38

Hollands RG (2008) Will the real smart city please stand up? City 12(3):303-320

Joss S, Cook M, Dayot Y (2017) Smart cities: towards a new citizenship regime? A discourse analysis of the British smart city standard. J Urban Technol https:// doi.org/10.1080/10630732.2017.1336027.

Joss S, Cowley R, de Jong M, Müller B, Park BS, Rees W, Roseland M, Rydin Y (2015) Tomorrow's city today: prospects for standardising sustainable urban development. University of Westminster/International Eco-Cities Initiative, London

Moldrich C (2017, September 27) Ford's new smart benches are an oasis of tech-and they're coming to London. Alphr Newsletter, http://www.alphr. com/environment/1007164/ford-s-new-smart-benches-are-an-oasis-of-techand-they-re-coming-to-london. Accessed 20 Oct 2017

NESTA (2015) Rethinking smart cities from the ground up. https://www.nesta.org. uk/publications/rethinking-smart-cities-ground. Accessed 20 Oct 2017

Ford Social (2017) No more \#FOMO's for London's pedestrians?. http://social.ford. co.uk/no-more-fomo-for-londons-pedestrians/. Accessed 20 Oct 2017

Fraser N (1990) Rethinking the public sphere: a contribution to the critique of actually existing democracy. Social Text 25/26:56-80

Newman J, Clarke J (2009) Publics, politics and power: remaking the public in public services. Sage, London
Saunders T, Baeck B (2015) Rethinking smart cities from the ground up. NESTA, London

Shelton T, Zook M, Wiig A (2015) The actually existing smart city. Camb J Reg Econ Soc 8(1):13-25

Strawberry Energy (nd) Enhancing the smartness of public places http://senergy.rs/ o-nama/?lang=en. Accessed 20 Oct 2017.

Taylor Buck N, While A (2015) Competitive urbanism and the limits to smart city innovation: The UK future cities initiative. Urban Stud https://doi.org/ $10.1177 / 0042098015597162$.

Young IM (1989) Polity and group difference: a critique of the ideal of universal citizenship. Ethics 99(2):250-274

\section{Acknowledgements}

This work was supported by the Economic and Social Research Council (grant no. ES/ L015978/1).

\section{Additional information}

Competing interests: The author declares no competing interests.

Reprints and permission information is available online at http://www.nature.com/ reprints

Publisher's note: Springer Nature remains neutral with regard to jurisdictional claims in published maps and institutional affiliations.

cc) (i) Open Access This article is licensed under a Creative Commons Attribution 4.0 International License, which permits use, sharing, adaptation, distribution and reproduction in any medium or format, as long as you give appropriate credit to the original author(s) and the source, provide a link to the Creative Commons license, and indicate if changes were made. The images or other third party material in this article are included in the article's Creative Commons license, unless indicated otherwise in a credit line to the material. If material is not included in the article's Creative Commons license and your intended use is not permitted by statutory regulation or exceeds the permitted use, you will need to obtain permission directly from the copyright holder. To view a copy of this license, visit http://creativecommons.org/ licenses/by/4.0/

(C) The Author(s) 2018 